\title{
Паляти лыслителя
}

DOI: $10.37005 / 2687-0231-2020-0-12-57-63$

УДК 304

\section{Н. Г. Багдасарьян}

Универсальная история как образ жизни

Наши тела состоят из пепла давно угасших звезд. Дж. Джинс

\section{Аннотация:}

Рассматривается наследие А. П. Назаретяна - мыслителя чрезвычайно широкого диапазона, одного из разработчиков международного исследовательского проекта Универсальной истории (в англоязычных странах Big History, в испаноязычных Megahistoria, в германоязычных - Weltallgeschichte), постдисциплинарного, или проблемного знания, представляя в нем Россию. Он приложил немало усилий к внедрению концепции в университетское образование, в частности, читал курс в Университете «Дубна». Подробно рассматривается его глава в учебнике для магистрантов и аспирантов «История, философия и методология науки и техники», посвященная эволюции типов миропонимания.

Ключевые слова: А. П. Назаретян, Универсальная история, Мегаистория, постнеклассическая наука, миропонимание, постдисциплинарное знание

Об авторе: Багдасарьян Надежда Гегамовна, доктор философских наук, профессор, Государственный университет «Дубна», зав. кафедрой социологии и гуманитарных наук; профессор МГТУ им. Н.Э. Баумана; эл. почта: ngbagda@ mail.ru

Эпиграф я позаимствовала у Акопа Погосовича, он поместил его в одной из своих книг, перед главой под названием «Набухающая Вселенная». И сам эпиграф, и название главы, и название книги [6, с. 192] - все показалось уместным в разговоре о Назаретяне.

Есть имена ученых, которые стоят особняком в научном сообществе. Их карьерная траектория не носит линейного характера - от одной ступени к другой - наверх, она строится по мере и в зависимости от того, как движется его мысль, как меняется собственная внутренняя логика роста знания. Интересы и проблемные поля таких исследователей, расширяясь и переплетаясь, выходят за конкретные дисциплинарные рамки. Их не слишком волнуют институциональные статусы, которые представляют интерес лишь постольку, 
поскольку они позволяют просвещать людей и популяризировать новое знание. Именно таким - открытым и глубоким, ценящим любознательных студентов и огорчающимся, если на него обращены глаза равнодушные, преданным идее Мегаистории, но энциклопедически образованным - представляется мне профессор Назаретян.

Акоп Погосович был моим другом, мы много общались и в университетских аудиториях, на конференциях и семинарах, и за пределами официальных мест. Выяснилось, что наши родители были в одно и то же послевоенное время в Риге, и, скорее всего, были знакомы. Зная занятость, востребованность и активность профессора, я и не помышляла о возможности пригласить его в Дубненский университет, и лишь однажды, рассказывая о своей кафедре, почти пошутила, что его там не хватает. К моему удивлению, он заинтересовался Университетом, учебным и научным направлениями кафедральной работы, приехал на конференцию, а потом и остался преподавать, проработав с нами около пятнадцати лет. 15 февраля 2019 г. его не стало. А в Университете теперь есть аудитория его имени.

Сегодня, когда кафедра уже второй год живет без профессора Назаретяна, все более очевидно, что заменить его некем, да и невозможно. Космос его интеллекта, обаяние личности, огромная эрудиция, дружеская готовность к участию во всех общественных делах делали Акопа Погосовича любимым членом коллектива.

За свои 70 лет А. П. Назаретян многое успел, он - доктор философских наук, кандидат психологических наук, эксперт РАН. Параллельно с университетом«Дубна» он руководил Центром Мегаистории и системного прогнозирования Института востоковедения РАН, читал лекции в МГУ им. М. В. Ломоносова, РАГСе, в других университетах России, куда его охотно приглашали. Часто выезжал за рубеж на конференции и для чтения лекций в странах Западной Европы и Латинской Америки, свободно владея английском и испанском языками. Последнее его турне по Латинской Америке осуществилось за несколько месяцев до ухода из жизни. Темы касались проблем культурной антропологии, политической психологии, психологии стихийного массового поведения; методов социального прогнозирования; психологии социальной безопасности. Он консультировал политических лидеров различного уровня в России, СНГ и других странах по вопросам проведения избирательных кампаний, предотвращения и оперативного устранения социальных конфликтов. Но главной темой последних десятилетий была Универсальная история.

В 1991 г. он опубликовал одну из первых концепций Универсальной истории («Мегаистория», Big History), которую продолжал далее разрабатывать в рамках системносинергетической модели. Такой подход позволил выявить ряд фундаментальных преемственных векторов и механизмов, реализующихся в различных сферах и на различных 
стадиях универсальной эволюции: правило избыточного разнообразия, закон иерархических компенсаций, закон техно-гуманитарного баланса и др. Редкая работа по проблемам техносферы, развития сложных социокультурных систем обходится без обращения к этим категориям.

А. П. Назаретян основал и до последних дней являлся главным редактором журнала «Историческая психология и социология истории», в редколлегию которого пригласил и меня, сам входил в редколлегии ряда ведущих научных журналов. Его работы были переведены на английский, испанский, японский языки. Ему нравилась научно-популяризаторская деятельность на радио и телевидении. Однажды мы даже оказались приглашены в одну и ту же программу на ОТР в цикле «Большая наука», где обсуждалась проблема времени. Но сами узнали об этом, лишь столкнувшись лицом к лицу на студии в Останкино.

Акоп Погосович - один из самых цитируемых российских исследователей. Он - автор около 370 публикаций, включая монографии и учебные пособия. На моей книжной полке - 6 его книг $[2 ; 3 ; 4 ; 5 ; 6 ; 7]$. И еще одна, которая мне особенно дорога. Как хорошо, что я увлекла коллегу идеей создания учебника для магистрантов и аспирантов по истории, методологии и философии науки и техники, и он написал туда целую главу. Учебник, в котором третьим соавтором стал другой крупный ученый, Виталий Георгиевич Горохов, вышел в издательстве «Юрайт» и переиздается ежегодно [1].

Глава, написанная Назаретяном, не носит, как это часто бывает, сугубо учебного характера, то есть, когда автор транслирует уже устоявшееся в науке знание. Это был его собственный подход и собственный взгляд. Если честно, она немного выбивалась из общей канвы нашей книги, когда передо мной стояла проблема ее редактирования. Но теперь, пролистывая этот текст, понимаю, как этот материал уместен в логике философии и методологии науки.

Назаретян концентрирует внимание на процессах дифференциации и интеграции, происходящих в современной науке, для чего рассматривает их через призму истории, выявляя последовательность и логику в смене типов миропонимания. При этом выясняется, что смена миропонимания во многом сопряжена с представлениями о причинности и целенаправленности, субъекте и объекте, хотя сами эти категории обозначились лишь на достаточно поздних этапах культурного развития. В этом подходе вновь и вновь проявилось панорамное мышление Акопа Погосовича, его поразительная эрудиция и парадоксальность аналогий. Апеллируя к Л. Леви-Брюлю, который ввел понятие «дологическое мышление», вызывавшее множество споров в первой половине прошлого века, он отталкивается от понятия синкретического, нерасчлененного мышления и приводит хрестоматийный пример: 
«Люди первобытного племени заявляют: «Мы львы» - и настаивают на том, что они не «как львы», не «похожи на львов», а именно являются львами. «Но ведь вы - люди?»-недоумевает европейский собеседник. «Да, мы люди, но мы - львы». Кажется, они не чувствуют противоречия между утверждениями, что некто есть человек и в то же время - лев. В наше время такой способ выражения, парадоксальный и аллегоричный, свойствен художникам и поэтам: «Речка движется и не движется...». Свойствен он также маленьким детям и людям в возбужденном эмоциональном состоянии («Женская логика?»). Научное же и даже здравое обыденное мышление нетерпимо к таким противоречиям и стремится их избегать.

На этом основании Леви-Брюль и его последователи доказывали, что первобытный человек нечувствителен к логическим противоречиям и вообще мыслит помимо всякой (во всяком случае, «аристотелевской») логики. Оппоненты возражали по-разному, но самый остроумный аргумент привели лингвисты. Они обратили внимание на относительную бедность лексической и понятийной структуры первобытного языка. В нем отсутствует, например, абстрактное понятие «храбрость» как свойство, отъемлемое от носителя. Поэтому там, где современный европеец может сказать: «Мы храбры, как львы, а они трусливы, как зайцы», - туземец говорит: «Мы львы, а они зайцы». Только таким образом он способен на своем языке выразить сходство качеств, наделить предмет свойством, присущим другому предмету» [1, с. 288-289].

В синкретическом мышлении, по существу, «не различаются причина и цель, а тем более - субъект и объект. Не различаются - потому, что все объекты наделены качествами, которые мы бы теперь назвали субъектными (и субъективными) качествами, а причинами всегда служат субъективные намерения» [1, с. 290]. Проследив соотношение объекта и субъекта на всех этапах развития научного знания, он определяет субъектность, как существенную характеристику постнеклассического его этапа: методологически рефлексируется неразрывная связь объекта и субъекта знания и то обстоятельство, что наблюдатель всегда имеет дело с реальностью не непосредственно, а через посредство культурно обусловленных метафор. То есть, субъектность современной науки, отличаясь от субъектности дологического мышления, обогащена и опосредована культурой.

Другая характерная черта постнеклассической науки - в сближении причины и цели, но и здесь это проявляется, разумеется, иначе, чем на ранних этапах синкретического мышления. Главное, к чему устремлена научная мысль, и вокруг чего организуется научное знание - это попытка разрешить те проблемы, которые накопила человеческая цивилизация, выйдя на очередной виток кризиса. В качестве примера А. П. Назаретян называет экологию. Это «не отдельная дисциплина, а проблемное поле, работа в котором требует знания 
термодинамики и энергетики, биологии, этологии, социологии и психологии» [1, с. 345]. Эта же особенность «относится едва ли не к любой масштабной проблеме, от чисто теоретических (эволюция, антропогенез и т.д.) до сугубо практических (энергообеспечение и энергосбережение, перепроизводство или товарный дефицит, разработка политических и экономических стратегий и т.д.) - все они теперь осознаются как проблемы междисциплинарные» [1, с. 345].

В этом поле - постдисциплинарного, или проблемного знания и развивается международный исследовательский проект Универсальной истории (в англоязычных странах Big History, в испаноязычных - Megahistoria, в германоязычных - Weltallgeschichte), к разработке и внедрению которого в университетское образование Назаретян приложил немало усилий, включившись в этот проект и представляя в нем Россию.

Вектор моего научного интереса не всегда совпадал с назаретяновским, различались и некоторые оценки исторических событий и процессов. Но был один вопрос, к которому мы шли разным путем (Акоп Погосович - через Универсальную историю, я - через философию техники и инженерного образования), но сошлись в общей точке. Точке, которая была обозначена им как закон техно-гуманитарного баланса. Кажется, впервые он формулирует его как гипотезу в работе 2001 г.: «Растущий технологический потенциал делает социальную систему менее зависимой от состояний и колебаний внешней среды, но вместе с тем более чувствительной к состояниям массового и индивидуального сознания» [7, с. 99]. Он возвращался к этой идее вновь и вновь в работах, изданных в разные годы, помещая ее в разные контексты, подчеркивая углубление угрожающего дисбаланса «между ускоренно развивающимися технологиями и снижающимся качеством гуманитарной культуры» $[4$, c. 130]. И вывод, который напрашивается из этого закона - об универсальном естественном отборе цивилизаций. Механизмом отбора жизнеспособных носителей разума может в таком случае служить уже известный нам закон техно-гуманитарного баланса: субъекты, не сумевшие совладать с возрастающим инструментальным могуществом, выбраковываются из дальнейшего эволюционного процесса, подорвав основы собственного существования... И только мудрый интеллект имеет шанс стать универсальным [6, с. 261].

Интересно, что и в этой, и в других работах Акопа Погосовича всегда угадывалось и проявлялось его профессиональное психологическое начало. Так, описывая античное мировоззрение, он подчеркивал, что это мировоззрение сочеталось с эмоциональными настроениями и ожиданиями: «Ионики, материалисты, как правило, пессимистичны, ибо полагали, что мировая гармония - результат слепого случая, и тот же слепой случай способен в любой момент разрушить этот мир. Так рассуждал, например, Гераклит, который скорбел о 
грядущем развале мироздания, превращении его снова в «кучу мусора», из какового он и образовался. Не случайно современники называли этого философа Плачущим. У италиков же мир организован разумным началом, которое вечно уберегает его от разрушения. Оттого они более жизнерадостны, оптимистичны» [1, с. 293]. Вместе с тем, его эрудиция и познавательная энергия выходила далеко за пределы социально-гуманитарного знания. Его интересовал космос в самом широком смысле этого слова - от Метагалактики до микроструктур Вселенной. И вся информация «шла в дело», которым было построение интегральной эволюционной картины мира, включающей историю космической Вселенной, жизни, общества, культуры и разума как органические фазы и составляющие единого процесса. Ни много, ни мало.

В подборке, посвященной памяти профессора Назаретяна, еще 3 статьи. Их авторы: Е. Сажиенко - его аспирантка, не успев защититься при жизни своего научного руководителя, все же довела дело до конца - уже с моей помощью (думаю, Акоп Погосович был бы нами доволен); Л. Карнацкая - его коллега, психолог, большой друг и помощница во многих делах; И. Шимон - коллега, профессор нашей кафедры, с размышлениями о значении наследия Назаретяна.

\section{Библиографический список:}

1. Багдасарьян Н.Г., Горохов В.Г., Назаретян А.П. История, философия и методология науки и техники: учебник и практикум для бакалавриата и магистратуры / под общ. ред. Н.Г. Багдасарьян. М.: Издательство Юрайт, 2014. 2020. 383 с.

2. Назаретян А.П. Агрессивная толпа, массовая паника, слухи. Лекции по социальной и политической психологии. СПб.: Питер, 2003. 192 с.

3. Назаретян А.П. Антропология насилия и культура самоорганизации: Очерки по эволюционно-исторической психологии. М.: Издательство ЛКИ, 2007. 256 с.

4. Назаретян А.П. Глобальное прогнозирование в свете Мегаистории и синергетики. Очерки истории будущего. М.: ИВ РАН, 2018. 260 с.

5. Назаретян А.П. Психология стихийного массового поведения: Толпа, слухи, политические и рекламные кампании: Учеб. пособие для студ. высш. учеб. заведений. 2-е изд., перераб. М.: Издательский центр «Академия», 2005. 160 с.

6. Назаретян А.П. Цивилизационные кризисы в контексте Универсальной истории. (Синергетика - психология - прогнозирование): 2-е изд. М.: Мир, 2004. 367 с.

7. Назаретян А.П. Цивилизационные кризисы в контексте Универсальной истории: Синергетика, психология и футурология. М.: ПЕР СЭ, 2001. 239 с.

\section{Bagdasaryan N.G. Universal History as a Way of Life}

We consider the legacy of A.P. Nazaretyan, a thinker of an extremely wide range, one of the developers of the international research project of Universal History (in English-speaking countries 
Big History, in Spanish-speaking countries Megahistoria, in German-speaking countries Weltallgeschichte), post-disciplinary, or problem knowledge, representing Russia in it. He has made many efforts to introduce the concept into university education, in particular, reading a course at Dubna University. His chapter in the textbook for undergraduate and graduate students "History, Philosophy and Methodology of Science and Technology" on the evolution of types of worldview is discussed in detail.

Keywords: A. P. Nazaretyan, Universal History, Mega-history, Big History, Post-nonclassical science, worldview, post-disciplinary knowledge 